\title{
Correspondence
}

\section{Catholic-Jewish Dialogue}

To the Editors: Malachi Martin's article "Jewish-Christian Ceasefire: The Dialogue Is Over" (Worldview, January) is a misrepresentation of Catholic-Jewish relations.

In the first place, the Catholic movement, encouraged by Pope John, to purify the preaching of the Christian gospel from anti-Jewish trends was by no means completed with the work of Vatican II and the subsequent changes in Catholic religious education. On the contrary, the changes that were introduced made Christians more sensitive to the fact that the so-called teaching of contempt (Jules Isaac) is not an accidental addition to the Christian message that can easily be removed. The negation of Judaism is, alas, situated very deeply in the Church's life and closely connected with the proclamation of the gospel. Hence the movement recommended by Pope John still continues.

Is it inevitable that Christians express their faith by affirming themselves as the true Israel (and thereby negating the old Israel)? Is it necessary that Christians define their faith in opposition to the religion of Israel? If a religion that has achieved a cultural dominance such as Christianity attaches to its central

\section{ARTHUR GOLDBERG'S "THE ROAD TO PEACE IN THE MIDDLE EAST"}

Reprints of this article, which appeared in the February issue of Worldview, are available at special bulk rates: 10 copies@ @ $50 c$; $11-99$ copies (a 40c; 100 or more (a) 25c. All orders must be prepaid. message the negation of Jewish existence, it is hard to see how this can fail to translate itself into social and political realities. Again, then, the movement continues.

Secondly, it is a misrepresentation to ciaim that the State of Israel, and with it the worldwide Jewish community, has undergone a radical change through the conflict and the victory of the Six-Day War. It is a misrepresentation to depict Israel as an imperialist power dominating the Middle East, bent on oppressing the Palestinian people. The situation of Israel has not changed substantially through the war. Israel remains the successful, but always endangered, resolution of a Jewish liberation movement with roots in Jewish religion and the Zionist reaction against European anti-Semitism. Israel remains the affirmation of a people that had been condemned to victimhood for two thousand years. While the victory of the Six-Day War has introduced Israel to many difficult political problems, problems for which the various parties in Israel propose different political solutions, it is unjust to present Israel, and with it the Jewish community, as oppressors, even if one disagrees with this or that policy of the party in power or certain hard-line groups in Israel. It is unjust to attribute to the Israeli government, which Jewish voices in Israel continue to criticize, some sort of imperialistic design. Where harsh policies are adopted, they are born out of fear and despair.

Surrounded by the vast Arab world; devoid of resources such as oil that make her attractive to the world; isolated from other nations, even from her former friends, because of the oil boycott; and supported only by American power, which may turn out to be unstable and which, in any case, compromises her own social ideals-Israel is more threatened than ever. While the gov- ernment has had some military success, the problems created by these things remain enormous. No, the situation of the Jews and Judaism in the world has not changed much.

There is no foundation, therefore, in the suggestion that the Catholic Church and the Jewish community find themselves in such altered conditions that the interchange fostered by Pope John and accepted by many prominent members of the Jewish community has come to a stop.

What is true is that after the SixDay War the Jewish community in North America lost a good deal of interest in dialogue with Christians. At a moment which they regarded as crucial for their survival, they had found themselves surrounded by few friends. After the Yom Kippur War and the oil boycott, I suppose that the Jews are anxious about the outcome of the conflict and frightened by the isolation in which they find themselves. Dialogue with Christians does not seem a very pressing issue at this time. The Jews want to survive and survive as Jews, faithful to the tradition of humaneness and moral ideals. Is dialogue possible to a group that is gravely threatened and must gather all its strength to survive physically and at the same time to retain its soul?

Professor of Philosophy

Gregory Baum

St. Michael's College

University of Toronto

Toronto, Ont.

\section{... - Muslim Dialogue}

To the Editors: Malachi Martin's cogent remarks concerning JewishChristian dialogue in your January, 1974, issue made eminent sense. If dialogue is to continue, or, rather, a new dialogue begin, which seeks to encounter the problem of belief in the modern age, I suggest that it be not a dialogue but a trialogue, i.e., Jewish, Christian and Muslim. As Mr. Martin so lucidly described in his book The Encounter (1969), all three faiths spring from the same Near Eastern Semitic culture and (continued on $p .46$ ) 